\title{
Gendered Vulnerability to Climate Change Impacts in Selected Counties in Kenya
}

\author{
Daniel M. Nzengya and John K. Maguta
}

\section{Contents}

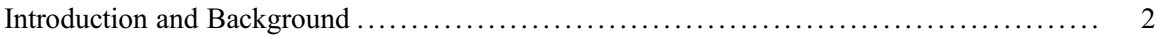

Overview of Global Perspectives of Climate-Induced Migration ................... 3

Climate-Induced Migration in Kenya: Causes and Implications ................... 5

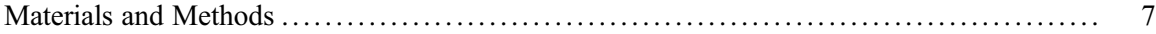

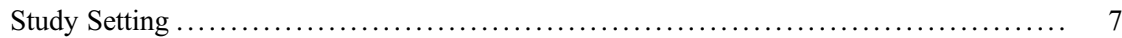

Data Analysis and Presentation of Results ................................. 7

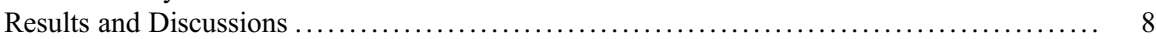

Climate Change Affects Women's Livelihood Differently from That of Men: Empirical

Evidence from the Study ............................................. 8

Ways in Which Experiences of Climate Change-Induced Migration Differed for Men and

Women ......................................................... 11

Measures by County Governments to Assist Communities Cope with Climate Change-

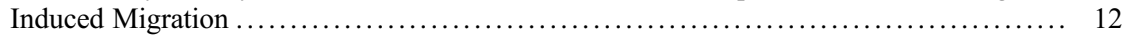

Measures by Nongovernmental Agencies to Assist Communities Cope with Climate

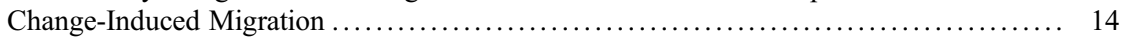

Lessons Learned, Study Limitations, and Recommendations for Future Research .......... 14

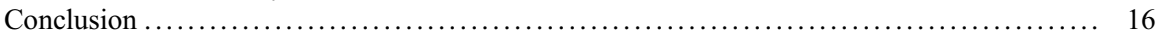

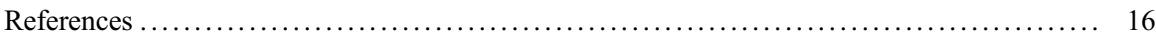

\section{Abstract}

Extreme climate change events such as frequent and prolonged droughts or floods associated with climate change can be very disruptive to peoples' livelihoods particularly in rural settings, where people rely on the immediate environment for livelihood. Shocks in the people's livelihoods can trigger diverse responses that include migration as a coping or adaption strategy. Migration takes many forms depending on the context and resources availability. Very few studies in Kenya have used qualitative analysis to bring up women's voices in relation to gender, climate change, and migration, especially along hydrological gradient. This

D. M. Nzengya $(\varangle) \cdot$ J. K. Maguta

Faculty of Social Science, St Paul's University, Limuru, Kenya

e-mail: dmuasya@spu.ac.ke 
chapter presents results of qualitative research conducted from 58 participants in 2018 in three counties in Kenya, namely, Kiambu County, Machakos, and Makueni. The study sought to examine gender perceptions related to climateinduced migration, that is: whether climate change is perceived to be affecting women's livelihood differently from that of men; examine in what ways experiences of climate induced migration differed for men and women; explore perceptions on the county government efforts to cope with climate-induced migration; and examine perceptions of the role of nongovernmental agencies in helping citizens cope with climate change. From the results obtained on ways in which climate change affected women livelihoods more than men had four themes: (1) women exerted more strain in domestic chores, child/family care, and in the farm labor; (2) women also experienced more time demands. The sources of water and firewood were getting more scarce leading to women travel long distances in search to fetch water and firewood; (3) reduced farm yields, hence inadequate food supply; and (4) the effects of time and strain demands on women was a contributory factor to women poor health and domestic conflicts. Several measures that the county government could take to assist women to cope with climate change-induced migration had five themes which include the following: (1) developing climate change mitigations, and reducing deforestation; (2) increasing water harvesting and storage; (3) develop smart agriculture through the use of drought-resistant crops and drought mitigation education; (4) encourage diversification of livelihoods; and finally (5) providing humanitarian assistance to the most vulnerable populations such as orphans and the very poor. Thirdly, the measures mentioned that NGO's could take to assist rural communities to cope with climate change-induced migration did not vary significantly from those mentioned for county government, except probably for a new theme of increasing advocacy for climate adaption policies.

\section{Keywords}

Climate change-induced migration $\cdot$ Hydrological gradient $\cdot$ Gendered vulnerabilities $\cdot$ Rural livelihoods $\cdot$ Kenya

\section{Introduction and Background}

Climate change poses one of the greatest challenges to rural livelihoods in the SubSaharan Africa (SSA). Sub-Saharan Africa is among the regions of the world where majority of people still reside in the rural areas. Millions of households in the rural populations rely on rain-fed small-scale subsistence agriculture (Kalungu et al. 2013). Subsistence agriculture has continued to face many sustainability challenges in the last 10 years, namely, worsening land degradation, declining farm outputs due to declining parcel of land associated with continuing subdivision due to rising population, inaccessibility to farm drought resistance seed crops, extreme climate change events, particularly more frequent and prolonged droughts (Kalungu et al. 
2013). Because rural population has risen during the last 15 years, increasing demands for farming and settlement has pushed communities to marginal and ecologically fragile lands, for instance, steep hill slopes, river banks, arid and semiarid areas (Ngugi et al. 2015). Poor land use practices have further exacerbated the continent' problem of soil erosion and desertification (Ngugi et al. 2015), further compounding population's vulnerability to extreme climate events such as droughts. It is estimated that climate change is partly responsible for the rural-urban migration in the SSA region, as people flee to towns and cities to pursue alternative livelihoods (Barrios et al. 2006; Hassan and Tularam 2018).

According to the Intergovernmental Panel on Climate Change, there is need to put in place mitigation and adaptation measures (Intergovernmental Panel on Climate Change 2018). It is because of climate change threats to human life that the United Nations took quick steps that resulted into holding conventions to mitigate climate change effects. According to the United Nations Framework Convention on Climate Change (UNFCCC) report developed from workshops held in 2006-2007 in Africa, Asia, and Latin America, all nations and people have a stake in reversing climatic changes (United Nations Framework Convention on Climate Change 2006). The UNFCCC paints a worrying report with claims that the developing countries are feeling the effects of climate change more than the developed ones. While developed countries have better and advanced coping mechanisms, the developing ones rely on crude means that leave them suffering the wrath of nature emanating from drought, excessive heat, and floods, and so on (Hurd and Smith 2004). There is need to put in place mitigation and adaptation measures as well as doing all that can be done to ensure the ecosystem remains balanced and conserved.

The objectives of this entry are to: (1) examine if climate change was affecting women's livelihood differently from that of men; (2) in what ways climate-induced migration differed for men and women; and (3) to examine the measures county government and nongovernmental agencies were taking assist communities cope with climate-induced migration.

\section{Overview of Global Perspectives of Climate-Induced Migration}

Extreme climate change events interact with many factors to trigger human migration. For instance, the rising trends in climate related disasters, such as severe and prolonged droughts, floods, in different regions of the world have forced people to migrate for safety or for survival. Van der Land and Hummel (2013) has argued that there has been a tendency of low rainfall forcing man to degrade the land. When land is degraded, the environment is affected even more. Further, planning for people has become harder. It is hard to allocate resources to populations that keep moving from one region to another when threatened by the same weather the populations have contributed to make unfriendly. When populations migrate, they further strain the resources of their new areas of settlement. Kartiki (2011) has expressed concern that the ensuing migrations are likely to increase conflicts and political stability. This, the author argues, will result from the struggle over the scarce resources and probably 
reshaping of geographical boundaries. International conflicts are likely to increase when countries share boundaries.

Chindarkar (2012) has lamented that climate change though painful to all leaves the female gender suffering more in comparison to men. The author argues that women are disadvantaged in terms of property ownership and getting education making them poorer. Failure to give women good education and allow them access to natural resources leaves them with little options to deal with hazards of climate change among other outcomes that include poor health and forced migrations. There are reduced economic activities that are based on natural resources resulting in food insecurity among other things. Climate change induced displacements of people as well as migrations and relocation have continued to take place making the UN to take climate change as an agenda that calls for urgent action (United Nations 2016). Several agencies including the United Nations have called upon organizations and individual countries to have measures in place to address displacement and migration of people (United Nations 2016). However, despite the calls and efforts of the $\mathrm{UN}$, migrations and displacements of people have been on the increase (Hassan and Tularam 2018).

Population movements occasioned by climate change are feared to adversely affect the poor and the vulnerable that have low coping mechanisms. Chindarkar (2012) has opined that since adaptation to and coping with climate change are gendered, women will continue to suffer as they have little income and access to natural resources in comparison to their male counterparts. Reduced access to food and water lays a bigger burden on women. As evidenced in the case of Chitwan Valley in Nepal, women are in most cases the primary collectors of the various provisions required by family members. Citing the case of Sonora in Mexico, the author states that the reduction of water affected the food processing industry forcing men to migrate to towns. The outcome was increase in the workload of women who were left with the burden of tending for families without the men who had migrated. In a similar trend, internal migrations have taken place quite to a large extent in the republics of Kiribati and Tuvalu as a result of induced climate change (Hassan and Tularam 2018). Majority of the people especially women in the Kiribati and Tuvalu rely almost entirely on agricultural-related activities.

The gender divide puts a heavier burden on women who are tasked with looking for water and much more often searching for food. The socially constructed gender differences heap the obligations and the burden of caregiving on women. Since the economic muscle needed to acquire food and water is in many cases lacking, as men monopolize this, women are left with no option but to trek long distances looking for the commodities. Kolmannskog (2009) in a study conducted in Somalia and Burundi has stated that women who are left behind by their husbands face another fear of being chased away by families or relatives of their husbands. When husbands migrate in search of better pastures for their animals, women and children are left behind with relatives.

This has been the trend in Mexico where apart from destroying plants and aquatic life, health has been affected through water pollution and sedimentation. Studies conducted in Bihar and Uttarakhand in India have confirmed that the people who 
have limited access to resources are more vulnerable and suffer more from climate change effects. Adding their voices to the debate on climate change-induced migrations, Waldinger and Fankhauser (2015) have opined that it increases incentives to migrate. Inability to cope with induced climate change has called for emergency relief and security for those affected (Serdeczny et al. 2017). The authors further argue that internal displacements have resulted in greater risks especially sexual and gender-based violence for women. The latter authors have claimed that when people have to move as a result of weather, the dressing code has compounded the problem like what happened to the Indian women during the Indian Ocean tsunami in 2004. The mode of dressing for Indian women is not suited for walking fast and covering long distances. Further, climate-induced migrations and displacements often lead to breaking of social networks and psychological impacts that are lasting. The authors here have argued that women feel the impact of climate change-induced migrations more deeply. In many cases, they are left with no choice but to think of themselves as well as their entire families. The situation becomes even worse for women as they are rarely allowed direct access to relief food and other emergencies due to cultural constrains. The scenario portrays a potential risk of women falling victims of sexual exploitation or even worse to be trafficked. In countries like Bangladesh and Philippines, due to their low education, women are subjected to low-working paying jobs with long working hours. They are employed as domestic house-helps who have to contend with mistreatments in order to earn bread. Climate-induced migration is not only dangerous but has also turned into a poverty trap (Rahman 2013).

Climate change has forced people to adapt into new cultures in order to survive. Chindarkar (2012) has cited the case of Bangladesh women who have migrated to India. For fear of detection and eventual deportation, many have adorned Hindu religious markers especially on their foreheads.

In Mali and Senegal both of which are in Africa, climatic changes have adversely affected subsistence farming and livestock rearing. Since this Sahel region of West Africa has majority of the people relying on the rains that have been declining, migration has become a common phenomenon (van der Land and Hummel 2013). With a good number being illiterate or semiliterate, farming has been the only way to as they cannot be absorbed in gainful employment that require skills. Waldinger and Fankhauser (2015) have claimed that people involved in the agricultural sector in developing countries will continue suffering climate shocks like droughts and flooding (also, see IPCC 2018). These are attributed to weak financial muscle and use of low technology.

\section{Climate-Induced Migration in Kenya: Causes and Implications}

Like the rest of the world, effects of climate change are being felt in Kenya. This is proved by the erratic and unpredictable weather patterns. Cuni-Sanchez et al. (2019) content that the amount of rainfall, fog, and temperature has witnessed serious variations in the last few decades. Rain seasons have changed making it hard to predict the weather and prepare land in good time for farmers. With the high reliance 
on rain-fed agriculture, variability of rains has threatened food security and complicated lives mainly in rural areas. Droughts and flooding are now a common thing with crops being destroyed. Desertification has increased making life even tougher especially for pastoralists whose livestock have faced grass shortages. Livelihoods have been destroyed with vulnerability increasing by the day. Migrations mainly to urban centers for wage employment especially by men have been taken as the option by some of the affected. Like in other countries, women have been left behind to cater for the families (IPCC 2018).

Climate variability in Kenya like the rest of the world has been blamed largely on human activities. As Sheikh (2017) has argued in a study of Dadaab area of North Eastern Kenya, human-related activities have led to stiff competition over resources which in turn has led to increased conflicts. The increased conflicts have compounded [the problem created the?] movement of people from one place to another. Further, the internally displaced persons in the country are exposed to other vices that include sexual and gender-based violence, dependency, instability, and living in fear as the future remains uncertain. With the scarce resources in the country, migrations emanating from climate change are a major threat to the wellbeing of all as one is either directly or indirectly affected. Sabbarwal (2017) has lamented on increasing temperatures in Turkana region with conflicts increasing as people compete over reducing pasture and water resources. The author claims that with the area drying up and with temperatures having gone up by approximately $2{ }^{\circ} \mathrm{C}$ between 1967 and 2012, raids and migrations have been common. With the rainy seasons becoming shorter and drier, women and girls who are charged with the duties of fetching water have no option but to trek long distances to get the diminishing resource. Water has to be extracted by digging dry wells and riverbeds. With the reduced pastures, animals have died or become famished.

Cuni-Sanchez et al. (2019) carried out a study in northern Kenya and noted a lot of climatic changes in Mt. Kulal, Mt. Nyiro, and Mt. Marsabit. Natural rivers had turned into seasonal rivers. Reliance on firewood and other non-timber products had been affected greatly by changing climate. The unreliability of rains that at times would come when not expected and in low quantities forced people to device different coping mechanisms which include migrations.

Climate-induced migrations have complicated life for those affected and created problems to the government (Corburn et al. 2020). Corburn and others (2020) recent work have pointed to Kenya's urban slums to a haven for COVID-19 infections. Some demographic projections estimate that over half of citizens in Kenya's capital, Nairobi reside in the slums (UN-Habitat n.d.). This has made it hard to share resources like water and housing. Both the national government and the county government have to struggle in provision of public goods and services to the slum population that is increasing by the day. Security has become an issue while environmental health has become an eyesore with dirt in the congested settlements becoming a nuisance. 


\section{Materials and Methods}

This study employed use a qualitative cross-sectional survey design. Data were collected in 2018 from three counties using questionnaire with open-ended questions. The open-ended questions included: (1) if climate change was affecting women's livelihood differently from that of men; (2) ways in which climate change-induced migration of women differed from those of men; (3) the initiatives the county government should undertake to help people cope with climate change; and finally, (4) the participants' perceptions of the measures nongovernmental agencies should undertake to assist communities cope with climate change.

\section{Study Setting}

The research was conducted at three counties in Kenya which are Kiambu, Machakos, and Makueni counties. The Kiambu county is generally lies at a higher attitude, is generally cool with high amounts of rainfall, followed by Machakos, with Makueni being classified as arid and semiarid county. The Kiambu County is generally wet, and the average annual rainfall for the Kiambu is $1000 \mathrm{~mm}$ annually. Machakos County, on the other hand, receives average rainfall, with some parts of the county experiencing similar weather patterns as Kiambu County, and other parts being relatively dry. Makueni County is classified as an arid and semiarid region. The county receives low amount of annual rainfall of $600 \mathrm{~mm}$. Makueni county experiences frequent and prolonged droughts triggering crop failures, and is among the list of counties in that receives relief food to mitigative starvation, malnutrition.

\section{Data Analysis and Presentation of Results}

This study used content analysis (Hsieh and Shannon 2005) and inductive coding (Strauss and Corbin 1998). Content analysis is a "technique for making inferences by objectively and systematically identifying specified characteristics of messages" (Holsti 1969, p. 14). Content analysis allows a blend of both quantitative and qualitative data analysis attributes to be combined. That is, the researchers can identify count data and compute frequencies/percentages for further analysis. In addition, these quantitative measures can be supported with themes/categories. This method was adopted due to the short nature of responses that was generated from the survey open-ended questions. There were two coding cycles. The first cycle enabled the researchers to describe the data. In the second coding cycle, the codes identified in the first cycle were compared, organized, and categorized (Tracy 2013). To increase credibility of the coding procedure, two people were involved, one of the researchers and a colleague who is familiar with the subject matter. The two researchers did both coding cycles together and where there was a disagreement, they discussed until they reached an agreement. Where possible thick descriptions 
were identified to support the themes/categories identified. In this study, the unit of analysis was the respondent and each of the four question were analyzed separately to identify themes.

\section{Results and Discussions}

\section{Climate Change Affects Women's Livelihood Differently from That of Men: Empirical Evidence from the Study}

Twenty two percent of the respondents did not think climate affects women's livelihoods differently than men. However, $88 \%$ of the respondents felt climate affected women's livelihoods differently from men. Table 1 summarizes the different themes emerged from the analysis of qualitative responses to the question "in what ways does climate change affect women's livelihoods differently from that of men." Four themes, namely, more strain, low income, time demands, and effects of time and strain demands. The theme "more strain" can be described as "exert extra effort in carrying out domestic and farm related chores." This theme was comprised of four themes described in Table 1, namely, domestic shores, child/family care, and farm labor. Women in the rural areas in many parts of the SSA, particularly in Kenya, bear disproportionate burden of household chores (Muasya and Martin 2016; Mokomane 2014). As men migrate to towns and cities to look for better income opportunities, this adds to the burden women bear as a consequence of climate change particularly prevalent and prolonged droughts. Majority of rural areas lack access to reliable and/ or affordable water sources, and most households rely on surface water resources for household and domestic needs (Kelly et al. 2018). Most of these sources are seasonal rivers and water springs which run dry during dry spell, meaning women have to walk longer distances during drought seasons to look for the scarce commodity (Cherutich et al. 2015). As one of the participants A1 remarked:

women are more burdened as they have to source for their families' necessities

while participant B1 had the same concerns:

Women travel long distances searching for water for domestic use apart from caring for the family

Also, unlike urban areas where working class women hire house helps to assist with child care and other family chores (Muasya 2014), women in rural areas grapple with insufficient resources for survival, meaning they have to bear the burden of child and family care demands. Previous studies have shown that where husbands are present, they provide some support in these tasks reducing stress related to child/ family care and work-balance conflicts (Muasya 2016). However, as men migrate to towns and cities, rural women have to bear the extra burden of attending to family chores while carrying children on their backs. As one participant B2 commented: 
Table 1 Ways in which climate change affected women livelihood differently from that of men

\begin{tabular}{|c|c|c|c|c|}
\hline Themes & Subthemes & Explanation & $\begin{array}{l}\text { No of } \\
\text { mentions }\end{array}$ & $\%$ \\
\hline \multirow[t]{3}{*}{ More strain } & Domestic chores & $\begin{array}{l}\text { Women faced more strain as most of } \\
\text { the household chores were assigned } \\
\text { to them. For instance, collecting } \\
\text { firewood and fetching water }\end{array}$ & 4 & 6.45 \\
\hline & Child/family care & $\begin{array}{l}\text { Women faced more strain from } \\
\text { taking care of the young ones }\end{array}$ & 5 & 8.06 \\
\hline & Farm labor & $\begin{array}{l}\text { Women had more responsibilities in } \\
\text { preparing the farm, cutting pasture } \\
\text { for animals, and harvesting }\end{array}$ & 6 & 9.68 \\
\hline \multirow[t]{2}{*}{ Low income } & $\begin{array}{l}\text { Low yields and } \\
\text { inadequate food } \\
\text { supply }\end{array}$ & $\begin{array}{l}\text { The farms yielded low yields, } \\
\text { leading to inadequate food supply } \\
\text { for the family and poor nutrition }\end{array}$ & 8 & 12.90 \\
\hline & $\begin{array}{l}\text { Women as bread } \\
\text { earners }\end{array}$ & $\begin{array}{l}\text { Women had to run small agro- } \\
\text { related businesses/farming to } \\
\text { supplement or basically provide for } \\
\text { the family }\end{array}$ & 10 & 16.13 \\
\hline \multirow[t]{2}{*}{$\begin{array}{l}\text { Time } \\
\text { demands }\end{array}$} & $\begin{array}{l}\text { More time } \\
\text { demands } \\
\text { searching water } \\
\text { and firewood }\end{array}$ & $\begin{array}{l}\text { Women had to walk long distances } \\
\text { searching for firewood and water }\end{array}$ & 10 & 16.13 \\
\hline & $\begin{array}{l}\text { More time } \\
\text { demands } \\
\text { searching food }\end{array}$ & $\begin{array}{l}\text { Women had to walk long distances } \\
\text { searching for food }\end{array}$ & 3 & 4.83 \\
\hline \multirow[t]{3}{*}{$\begin{array}{l}\text { Effects of } \\
\text { time and } \\
\text { strain } \\
\text { demands }\end{array}$} & Poor health & $\begin{array}{l}\text { Women were prone to sicknesses } \\
\text { due to effects of harsh cold weather } \\
\text { in the fields, and strain and } \\
\text { experienced cold-related sicknesses } \\
\text { such as colds, asthma, arthritis, } \\
\text { among others }\end{array}$ & 14 & 22.58 \\
\hline & $\begin{array}{l}\text { Domestic } \\
\text { conflicts }\end{array}$ & $\begin{array}{l}\text { The strain and time pressures } \\
\text { contributed to domestic conflicts } \\
\text { between the women and their } \\
\text { spouses }\end{array}$ & 2 & 3.22 \\
\hline & & & & 100 \\
\hline
\end{tabular}

Source: Authors' survey results, 2020

Women are more affected as they have to fetch water and take care of the young ones

It is estimated that rural women provide over $80 \%$ of farm labor in the rural areas at the SSA region (Ogunlela and Mukhtar 2009). Majority of the rural households lack resources for mechanization, meaning they rely on rudimentary tools and approaches to accomplish most of the farm activities, from digging, land preparation, planting, weeding, harvesting, and postharvest tasks (FAO 2011). As men and young people migrate to towns and cities to run-away from difficulties precipitated by climate change in rural areas, which means women have to bear the burden of accomplishing all these tasks on their own as participant A5 alluded: 
Women are more into the farms harvesting crops and also its preparation

The theme "low income" implies that women earned low income due to declining yields. This theme comprised two subthemes, namely, low yields and inadequate food supply, and low income from agro-related businesses. Rural women rely on selling a variety of farm produce for financial sustenance, and also to provide support to diverse family needs, from purchasing food to educating their children, farm produce consists the main supply of food and nutrition to families. In a study of stressors and work family conflict among urban female teachers, Muasya (2020) found that low income was a stressor to teachers with low income which further made them seek extra sources of income exacerbating their work life balance challenges. In addition, severe and prolonged droughts associated with climate change have been prevalent in the study sites, particularly Makueni County in the last 5 years, resulting into massive crop failures and livestock deaths (Amwata et al. 2015). This led to massive starvation, malnutrition, especially where humanitarian interventions are rarely available (Amwata et al. 2015). This is worsened as most men migrating to towns and cities end up in low-income informal employment and lack extra income to sustain their rural families left behind in rural areas. As one participant $\mathrm{C} 5$ remarked: Yes. Most of women depend on small scale farming which due to climate change do not
produce enough

This was echoed by participant C8,

Low yields make women struggle very much to find food

The theme "time demands" implies "women spent more time in household chores, farming than men who migrate to towns for industrial jobs." This theme comprised of two subthemes, namely, more time demands searching water and firewood, and more time demands searching food. Although for households living in urban areas, both men and women participate in paying water bills, energy bills, and purchasing food, on the contrast, in the rural areas in most parts of SSA region, women are the ones responsible for collecting water, firewood for cooking, looking for food and the cooking as well (Tian 2017). The burden of the multiple task of looking for food and the time expended walking long distances to look for water particularly during droughts, collecting firewood causes real strain and stress upon rural women (Tian Tian 2017). The quotes by two survey participants below highlight the predicament rural women face out of the experiences during extreme climate change events, particularly droughts. As participants A5, B3, and C4 remarked, respectively: 
The last theme identified was on the effects of time and strain demands. The results of the survey identified two subthemes that had to do with how participants perceived climate change events to affect women, namely, poor health and domestic conflicts. Many participants attributed the vulnerability of women to women's prolonged hours in the farms, or walking to collect water and/or firewood to increase the prevalence of illnesses such colds, asthma, arthritis, among others. Given that women have to carry along their infants during most of these tasks, participants were concerned that their infants and children were by extension exposed to the negative health effects experienced by rural women due to climate change.

Besides poor health, women experienced domestic conflicts. Too much strain and time pressures led to strained marital relationships between the spouses. The women could not be in a position to be equally present at home to take care of children, prepare food in good time, or even offer conjugal rights to their spouses. Studies have shown women even in the formal sector with no adequate support for child care tend to quit their work (Muasya 2017). On the other hand, delegation of house chores and childcare chores can be a source of conflict as well, when these women fail to undertake these chores as socially expected. Moreover, as more household and farm tasks are carried out by women than their spouses, these women can perceive it that their spouses have neglected their duties and it can result to more domestic strife. Indeed, lack of work life balance and delegation of chores can be a source of domestic conflict (Muasya and Martin 2016).

\section{Ways in Which Experiences of Climate Change-Induced Migration Differed for Men and Women}

Majority of participants $(90 \%)$ felt that that climate change-induced migration differed for men and women. Specifically, more men than women left home and migrated from rural areas to urban areas to look for alternative sources of income, search for pasture, or work in farms. Consequently, women were left with more responsibilities. The quotes below highlight participants perceptions on the different ways in which experiences of climate-induced migration differed for men and women as participant A10 narrated:

men migrate to look for jobs while women engage in simple chores to cater to-day-today needs

and participant $\mathrm{A} 12$ remarked:

most men migrate in search of alternative sources of livelihood while women remain behind to cope with the change

And participant B6 said:

diverse climatic change makes most men travel to towns leaving families behind 


\section{Measures by County Governments to Assist Communities Cope with Climate Change-Induced Migration}

Table 2 summarizes the different themes emerged from the analysis of qualitative responses to the question "measures by county governments to assist communities cope with climate change induced migration." Eight themes, namely, climate change

Table 2 Measures by county governments to assist communities cope with climate changeinduced migration

\begin{tabular}{|c|c|c|c|c|}
\hline Themes & Subthemes & Explanation & $\begin{array}{l}\text { No of } \\
\text { mentions }\end{array}$ & $\%$ \\
\hline $\begin{array}{l}\text { Climate change } \\
\text { mitigation/ } \\
\text { adaptation }\end{array}$ & & $\begin{array}{l}\text { Encourage reforestation, planting of } \\
\text { trees, agroforestry, and reduce cutting } \\
\text { of trees }\end{array}$ & 7 & 6.31 \\
\hline $\begin{array}{l}\text { Women } \\
\text { empowerment }\end{array}$ & & $\begin{array}{l}\text { Women empowered to make financial } \\
\text { decisions that can empower them }\end{array}$ & 6 & 5.40 \\
\hline \multirow[t]{2}{*}{$\begin{array}{l}\text { Strengthening } \\
\text { water adaptive } \\
\text { capacity }\end{array}$} & $\begin{array}{l}\text { Increased } \\
\text { water } \\
\text { harvesting and } \\
\text { storage }\end{array}$ & $\begin{array}{l}\text { One way to curb drought is increased } \\
\text { water harvesting storage through } \\
\text { provision of water harvesting resources } \\
\text { such as funds, materials, e.g., water } \\
\text { tanks, involved in sinking boreholes, } \\
\text { dam reservoirs }\end{array}$ & 47 & 42.34 \\
\hline & $\begin{array}{l}\text { Sensitization } \\
\text { on water } \\
\text { harvesting }\end{array}$ & $\begin{array}{l}\text { Women farmers to be sensitized on the } \\
\text { need of water harvesting and ways to } \\
\text { harvest water }\end{array}$ & 3 & 2.70 \\
\hline $\begin{array}{l}\text { Soil and water } \\
\text { conservation }\end{array}$ & & $\begin{array}{l}\text { The need to preserve soil and water } \\
\text { through measures such as gabions, } \\
\text { water friendly trees, curbing farming } \\
\text { along rivers, etc. }\end{array}$ & 8 & 7.21 \\
\hline \multirow[t]{2}{*}{$\begin{array}{l}\text { Climate smart } \\
\text { agriculture }\end{array}$} & $\begin{array}{l}\text { Drought- } \\
\text { resistant crops }\end{array}$ & $\begin{array}{l}\text { Farmers to grow drought-resistant and } \\
\text { fast-maturing crops with minimal } \\
\text { irrigation }\end{array}$ & 15 & 13.51 \\
\hline & $\begin{array}{l}\text { Drought } \\
\text { education }\end{array}$ & $\begin{array}{l}\text { Sensitization and education on drought- } \\
\text { tolerant crops and information on } \\
\text { weather patterns, e.g., from } \\
\text { meteorological department }\end{array}$ & 8 & 7.21 \\
\hline $\begin{array}{l}\text { Diversifying } \\
\text { livelihoods }\end{array}$ & & $\begin{array}{l}\text { Women to be encouraged to explore } \\
\text { other non-farm income-generating } \\
\text { activities }\end{array}$ & 6 & 5.40 \\
\hline $\begin{array}{l}\text { Humanitarian } \\
\text { assistance }\end{array}$ & & $\begin{array}{l}\text { The county and nongovernmental } \\
\text { organizations to identify and support } \\
\text { the most vulnerable groups to climate } \\
\text { change such as orphans and the very } \\
\text { poor }\end{array}$ & 5 & 4.50 \\
\hline \multirow[t]{2}{*}{$\begin{array}{l}\text { Individual and } \\
\text { institutional } \\
\text { capacity building }\end{array}$} & & $\begin{array}{l}\text { Enhancing the capacity of women and } \\
\text { the local institutions on ways to harvest } \\
\text { and conserve water }\end{array}$ & 6 & 5.40 \\
\hline & & & & 100 \\
\hline
\end{tabular}

Source: Authors' survey results, 2020 
mitigation and adaptation through tree planting; women empowerment; strengthening households' water adaptative capacity; soil and water conservation (resilience capital); promoting climate smart agriculture; sharing meteorological information/ data with rural households; promoting diversification of livelihoods; and targeted humanitarian assistance and strengthening individual and institutional capacity.

The theme on tree planting did not have many categories, and there was little variability of responses from sampled participants. Suggested items included "reforestation"; "sensitizing people to plant trees"; "educating residents on importance of planting trees"; "planting drives on water catchment"; "encouraging people to plant more trees"; "encourage people to avoid cutting down of trees"; and "encouraging tree nurseries." There are several ways in which these measures mentioned by participants can be linked to coping with climate change-induced migration. Planting trees becomes a source of income from the sales of animal fodder, firewood, fruits, thereby providing women with the need supplies to meet households and domestic needs. Some fruits planted in the study sites, particularly Machakos and Makueni Counties, include grafted mangoes that incidentally do well during seasons of crop failures, thereby acting as a buffer to household income and food supplies (Muema et al. 2018).

Women empowerment was another theme that emerged from the analysis of participants' responses regarding the open-ended question on what measures by county governments to assist communities to cope with climate change-induced migration. In most rural settings in the SSA region, patriarchal structures largely influenced decisions related to access to land for cultivation, farm inputs, harvest and postharvest, access to capital to support farm labor, access to capital for physical assets such as farm equipment, water harvesting, and improved cooking stoves (FAO 2011). Even where microfinance existed to support women's efforts, many women had to still seek consent from their spouses, even when the needs were pressing. Such patriarchal structures further limit or frustrates women's intention to build asset portfolio (social networks, human capital, natural capital, physical capital, and financial capital) necessary for climate resilience, and adaptation. The last decade or so has seen many countries including Kenya address women's marginalization particularly in relation to land inheritance, land ownership, and this has spillover benefits particularly reducing gendered vulnerabilities associated with climate change events such as droughts (FAO 2011).

The theme on strengthening households adaptative capacity has several subthemes, namely, increasing supply of materials for water harvesting/funds; supplying water tanks; drilling boreholes; digging dams and reservoirs; and sensitization of communities on water harvesting. Women and children, especially in the rural areas, suffer most problems associated with inaccessibility to reliable and affordable safe sources of water for household and domestic use (Graham et al. 2016). Consequently, improving water accessibility greatly improves the capacity of rural households to cope with climate induced migration, particularly when they are faced with limited human capital because men/husbands have migrated to towns and cities. Also, in pastoral communities, climate change-induced conflicts over diminishing water sources and pasture are quite common in the SSA (Witsenburg and Adano 
2009). Consequently, measures such as digging boreholes, water harvesting structures such as dams help communities to better cope with induced migration as they have access to more options in terms of water sources to support their livestock (Witsenburg and Adano 2009).

Soil and water conservation was another theme that was identified, and three subthemes, namely, gabions, water friendly trees on catchment areas, and avoiding farming near rivers. Soil erosion and bad land use practices such cultivating along rivers backs undermine the resilience capital rural dwellers desperately require coping with climate change-induced migration.

Climate smart agriculture is further identified to be another theme that emerged in the analysis of qualitative responses related to county government measures to assist communities to cope with climate-induced migration. Three subthemes identified here included: drought-resistant or fast-maturing crops/seeds; irrigation; and sensitization and education of drought-tolerant crops. Other themes identified included: sharing meteorological information/data with rural households; diversifying livelihoods; timely and strategic humanitarian assistance; and strengthening rural institutions.

\section{Measures by Nongovernmental Agencies to Assist Communities Cope with Climate Change-Induced Migration}

Six themes emerged from the qualitative analysis of participants' responses in relation to measure nongovernmental agencies have taken to assist communities cope with climate change-induced migration. Four of the themes seemed to overlap with measures undertaken by county governments. However, two of these themes differed significantly from the measures participants suggested in relation to the role of the county government, namely, climate change advocacy and diverse range of humanitarian interventions. Statements implying climate change advocacy were most frequently mentioned measures by respondents.

The range of humanitarian interventions that NGOs were involved with to assist communities cope with climate change and consequences of climate-induced migration included: supporting children from very poor families; providing food to poor families; providing medical care, providing mobile clinics for health; child sponsorship; providing cheaper energy options for cooking; and providing seeds for planting (Table 3).

\section{Lessons Learned, Study Limitations, and Recommendations for Future Research}

Rural households in the study sites observed that climate change affects women's livelihoods differently from men. Specifically, climate change exerts more strain on women, lowers their agro-dependent income due to crop failures and reduced yields, increases time demands women have to spend on household chores such as looking 
Table 3 Measures by nongovernmental agencies to assist communities cope with climate changeinduced migration

\begin{tabular}{l|l|l|l|l}
\hline Themes & Subthemes & Explanation & $\begin{array}{l}\text { No of } \\
\text { mentions }\end{array}$ & $\%$ \\
\hline $\begin{array}{l}\text { Adaptation through } \\
\text { water harvesting }\end{array}$ & $\begin{array}{l}\text { Providing water } \\
\text { harvesting } \\
\text { resources }\end{array}$ & $\begin{array}{l}\text { This water harvesting can be } \\
\text { achieved through provision of } \\
\text { water harvesting resources } \\
\text { and assistance in sinking } \\
\text { boreholes and dams }\end{array}$ & 7 & 8.33 \\
\cline { 2 - 6 } & $\begin{array}{l}\text { Water harvesting } \\
\text { education and } \\
\text { sensitization }\end{array}$ & $\begin{array}{l}\text { Provide water harvesting } \\
\text { education and sensitization to } \\
\text { communities }\end{array}$ & 2 & 2.38 \\
\hline $\begin{array}{l}\text { Climate change } \\
\text { advocacy }\end{array}$ & $\begin{array}{l}\text { Engage the communities and } \\
\text { government on policy change } \\
\text { to change to new ways of } \\
\text { farming technologies }\end{array}$ & 21 & $25 \%$ \\
\hline $\begin{array}{l}\text { Support livelihood } \\
\text { diversification }\end{array}$ & $\begin{array}{l}\text { Support climate } \\
\text { mitigation measures }\end{array}$ & & 10 & 11.90 \\
\hline $\begin{array}{l}\text { Climate smart } \\
\text { agriculture }\end{array}$ & $\begin{array}{l}\text { Humanitarian } \\
\text { intervention }\end{array}$ & & 15 & 17.48 \\
\hline
\end{tabular}

Source: Authors' survey results, 2020

for water as local water sources dry up, looking for firewood, and the effects of time and strain demands, and have negative impacts on women's, infants, and children's health. Rural communities felt that climate change-induced migration differed for men and women; specifically, more men than women left home and migrated from rural areas to urban areas to look for alternative sources of income, search for pasture, or work in farms. Consequently, women were left with more responsibilities. Regional/county governments' measures to assist communities cope with climate change-induced migration include: supporting climate change mitigation and adaptation through increased tree planting; women empowerment; strengthening households' water adaptative capacity; soil and water conservation (resilience capital); promoting climate smart agriculture; sharing meteorological information/ data with rural households; promoting diversification of livelihoods; targeted humanitarian assistance; and strengthening individual and institutional capacity. While nongovernmental agencies also participate in most of these measures, they seem to bring in strength in relation to climate change advocacy and a very diverse range of humanitarian interventions.

The study sample was limited the three counties in Kenya, and findings may not be generalizable in other parts of the SSA. The rural livelihoods communities studied are more-or-less sedentary, and future studies may need to focus on pastoral/nomadic 
communities. Also, the study investigated gendered vulnerabilities to climate change impacts and climate-induced migration largely among rural communities' settings. Future research will need to expand this work to urban settings and coastal communities.

The research design followed was cross-sectional survey, future studies are needed to include large sample, and probably use longitudinal designs to observe gendered vulnerabilities and climate-induced migration over a relatively longer study period.

In this study, trained research assistant participants filled responses to the openended questions according to participants answers. This limited the ability to capture participants emotions that can add perspective to the qualitative data collected. Future cross-sectional surveys would need to record participants narration, transcribe verbatim, the responses then analyze data.

\section{Conclusion}

Indeed, we can conclude that climate change does have negative effects on the livelihoods of rural women in a more disproportionate way compared to men. Thus, intervention whether through the county government or nongovernmental organizations may be required to factor in gender and socioeconomic factors in their policies and intervention programs. Failure to mitigate the negative effects of climate change in rural settings might worsen the livelihoods of women and children, undermining progress the sustainable development of reducing gender inequality, and also health for all citizens.

\section{References}

Amwata DA, Nyariki DM, Musimba NR (2015) Factors influencing pastoral and agro-pastoral household vulnerability to food insecurity in the drylands of Kenya: a case study of Kajiado and Makueni counties. J Int Dev 28(5):771-787

Barrios S, Bertinelli L, Strobl E (2006) Climatic change and rural-urban migration: the case of subSaharan Africa. J Urban Econ 60:357-371

Cherutich J, Maitho T, Omware Q (2015) Water access and sustainable rural livelihoods: a case of Elementaita division in Nakuru county, Kenya. Int J Sci Technol Soc 3(1):9-23

Chindarkar N (2012) Gender and climate change-induced migration: proposing a framework for analysis. Environ Res Lett 7(2):025601

Corburn J, Vlahov D, Mberu B et al (2020) Slum health: arresting COVID-19 and improving wellbeing in urban informal settlements. Yale School of Medicine. https://medicine.yale.edu/newsarticle/23734/. Accessed 5 July 2020

Cuni-Sanchez A, Omeny P, Pfeifer M, Olaka L, Mamo MB, Marchant R, Burgess ND (2019) Climate change and pastoralists: perceptions and adaptation in montane Kenya. Clim Dev 11(6): $513-524$

FAO (2011) The State of Food and Agriculture 2010-11 | FAO | Food and Agriculture Organization of the United Nations. Available at: http://www.fao.org/publications/sofa/2010-11/en/. Accessed 25 June 2020 
Graham JP, Hirai M, Kim SS (2016) An analysis of water collection labor among women and children in 24 sub-Saharan African countries. PLoS One 11:e0155981

Hassan OM, Tularam GA (2018) The effects of climate change on rural-urban migration in subSaharan Africa (SSA) - the cases of democratic Republic of Congo, Kenya and Niger. In: Applications in water systems management and modeling, vol 10. IntechOpen, London, pp 64-68

Holsti OR (1969) Content analysis for the social sciences and humanities. Addison-Wesley, Reading

Hsieh HF, Shannon SE (2005) Three approaches to qualitative content analysis. Qual Health Res 15 (9):1277-1288

Easterling WE III, Hurd BH, Smith JB (2004) Coping with global climate change: the role of adaptation in the United States. Pew Center on Global Climate Change, Arlington

Tollefson, J. IPCC says limiting global warming to $1.5 \mathrm{C}$ will require drastic action. Nature 2018, $562,172-173$.

Kalungu JW, Leal Filho W, Harris D (2013) Smallholder farmers' perception of the impacts of climate change and variability on rain-fed agricultural practices in semi-arid and sub-humid regions of Kenya. J Environ Earth Sci 3:129-140

Kartiki K (2011) Climate change and migration: a case study from rural Bangladesh. Gend Dev 19 (1):23-38

Kelly E, Shields KF, Cronk R, Lee K, Behnke N, Klug T, Bartram J (2018) Seasonality, water use and community management of water systems in rural settings: qualitative evidence from Ghana, Kenya, and Zambia. Sci Total Environ 628-629:715-721

Kolmannskog V 2009 Climate change, disaster, displacement and migration: initial evidence from Africa New Issues in Refugee Research No. 180 (United Nations High Commissioner for Refugees)

Mokomane Z (ed) (2014) Work-family interface in sub-Saharan Africa: challenges and responses. Springer, Cham

Muasya G (2014) The role of house helps in work-family balance of women employed in the formal sector in Kenya. In: Work-family interface in sub-Saharan Africa. Springer, Cham, pp $149-159$

Muasya G (2016) Work-family balance and immigrant sub-Saharan women in the United States. In: Communication and the work-life balancing act: intersections across identities, genders, and cultures. Lexington Books, London, pp 163-184

Muasya G (2017) Work-family conflict, support and intention to quit among Kenyan female teachers in urban public schools. S Afr J Labour Relat 41(1):33-45

Muasya, G. (2020). Stressors and work-family conflict among female teachers in urban public schools in Kenya. South African Journal of Education, 40(2).

Muasya G, Martin JN (2016) Conflict in Kenyan households: an exploratory study of professional women and domestic workers. Howard J Commun 27(4):385-402

Muema E, Mburu J, Coulibaly J, Mutune J (2018) Determinants of access and utilisation of seasonal climate information services among smallholder farmers in Makueni County, Kenya. Heliyon 4 (11):e00889

Ngugi L, Rao K, Oyoo A, Kwena K (2015) Opportunities for coping with climate change and variability through adoption of soil and water conservation technologies in semi-arid Eastern Kenya. In: Adapting African agriculture to climate change. Springer, Cham

Ogunlela YI, Mukhtar AA (2009) Gender issues in agriculture and rural development in Nigeria: the role of women. Humanit Soc Sci J 4(1):19-30

Rahman MS (2013) Climate change, disaster and gender vulnerability: a study on two divisions of Bangladesh. Am J Hum Ecol 2(2):72-82

Ravera F, Martín-López B, Pascual U, Drucker A (2016) The diversity of gendered adaptation strategies to climate change of Indian farmers: a feminist intersectional approach. Ambio 45 (Suppl 3):335-351

Sabbarwal S (2017) Indigenous peoples' concerns for environment: examining the role of nongovernmental organizations. Fourth World J 15(2):27-39 
Serdeczny O, Adams S, Baarsch F et al (2017) Climate change impacts in sub-Saharan Africa: from physical changes to their social repercussions. Reg Environ Chang 17:1585-1600

Sheikh AA (2017) Effects of climate variability on human migration dynamics: a case study of Ifo refugee camp, Daadab complex - Kenya, p 110

Strauss A, Corbin JM (1998) Basics of qualitative research techniques and procedures for developing grounded theory. Sage, Thousand Oaks

Tian X (2017) Ethnobotanical knowledge acquisition during daily chores: the firewood collection of pastoral Maasai girls in Southern Kenya. J Ethnobiol Ethnomed 13:2

Tracy SJ (2013) Qualitative research methods. Wiley-Blackwell, Chichester

UN-Habitat (n.d.) Kenya Habitat Country Program Document: 2018-2021 enhancing effective service delivery and sustainable urban development at national and county levels. UNHabitat, Nairobi

United Nations (2016) General adopts declaration for refugees and migrants as United Nations Organization sign key agreement. Retrieved from https:/www.un.org/press/en/2016/ga11820. doc.htm

United Nations Framework Convention on Climate Change handbook (2006) UNFCCC handbook. UNFCCC Climate Change Secretariat, Bonn

van der Land V, Hummel D (2013) Vulnerability and the role of education in environmentally induced migration in Mali and Senegal. Ecol Soc 18(4):14

Waldinger, M., \& Fankhauser, S. (2015). Climate change and migration in developing countries: evidence and implications for PRISE countries.

Witsenburg KM, Adano WR (2009) Of rain and raids: violent livestock raiding in Northern Kenya. Civ Wars 11(4):514-538

Open Access This chapter is licensed under the terms of the Creative Commons Attribution 4.0 International License (http://creativecommons.org/licenses/by/4.0/), which permits use, sharing, adaptation, distribution and reproduction in any medium or format, as long as you give appropriate credit to the original author(s) and the source, provide a link to the Creative Commons license and indicate if changes were made.

The images or other third party material in this chapter are included in the chapter's Creative Commons license, unless indicated otherwise in a credit line to the material. If material is not included in the chapter's Creative Commons license and your intended use is not permitted by statutory regulation or exceeds the permitted use, you will need to obtain permission directly from the copyright holder.

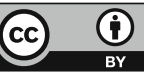

